\title{
Thermodynamic Study and Re-optimization of the Au-Ga Binary System
}

\author{
Dominika Jendrzejczyk-Handzlik ${ }^{1}$ (])
}

Submitted: 15 November 2016/in revised form: 21 March 2017/Published online: 5 April 2017

(c) The Author(s) 2017. This article is an open access publication

\begin{abstract}
Activities of gallium in the liquid Au-Ga alloys were determined using galvanic cells with the solid oxide electrolyte. The cells of the type:

$\mathrm{Au}_{x} \mathrm{Ga}_{(1-x)} / / \mathrm{ZrO}_{2}+\mathrm{Y}_{2} \mathrm{O}_{3} / / \mathrm{Fe}, \mathrm{FeO}$

were used in the temperature range from 1050 to $1273 \mathrm{~K}$, and for four alloy compositions $x_{\mathrm{Ga}}=0.2,0.4,0.6$ and 0.8 . From the measured e.m.f.'s the activity of gallium was derived, which taken together with the recently measured heat of mixing provided precise description of the thermodynamic properties of the liquid phase. This study was supplemented with DTA experiments which were performed for three alloy compositions, namely $0.15,0.25$ and 0.40 gallium mole fraction. The results of these experiments verified with temperature of respective invariant reactions. Finally, present results, taken together with the information existing in the literature, were used for the calculation of the optimized Au-Ga phase diagram. ThermoCalc software was applied to complete these calculations.
\end{abstract}

Keywords E.M.F. measurements · DTA method · Au-Ga phase diagram

This article is an invited paper selected from presentations at TOFA 2016, the Discussion Meeting on Thermodynamics of Alloys, held September 4-9, 2016, in Santos, Brazil, and has been expanded from the original presentation.

Dominika Jendrzejczyk-Handzlik

djendrze@agh.edu.pl

1 Faculty of Non-Ferrous Metals, AGH University of Science and Technology, 30 Mickiewicza Avenue, 30-059 Kraków, Poland

\section{Introduction}

The best known application of gold is in jewelry. A large variety of hand-made gold goods has been known since the ancient times. Recently, to push up the price of gold items, different colors of gold were introduced by addition of various alloying elements. ${ }^{[1-6]}$ Special colors of gold like purple, blue, or brown can be obtained using alloys of indium, gallium and aluminum. ${ }^{[7,8]}$

However, thanks to its high electrical conductivity and anticorrosion properties, gold has been also used in interconnections applied in modern electronics industry. In order to develop the improved contact materials and to adjust temperature of the solders, multicomponent alloys can be applied in which gallium can be one of the possible metallic solutes. Gallium has excellent wetting properties and decreases the temperature of melting. ${ }^{[9]}$ Used as a solder alloy, the $\mathrm{Cu}-\mathrm{Ga}$ system is a part of $\mathrm{Cu}-\mathrm{In}-\mathrm{Ga}-\mathrm{Se}$ photovoltaics $^{[10]}$ and $\mathrm{Cu}-\mathrm{Ga}-\mathrm{N}$ semiconductor systems. ${ }^{[11]}$ Kuznetsov and Shmelev ${ }^{[12]}$ investigated the influence of small gallium additions to gold and the interaction of AuGa alloys with silicon. They found that the increase of gallium concentration in the alloy results in the increase of stress in silicon. They also reported two isophlets determined for this ternary diagram containing 2.78 and 9.3 atomic percent of gallium. Gomidzelovic et al. ${ }^{[13]}$ investigated ternary Au-Ga-Sb system. Since Ga-Sb alloy belongs to the Group of III-V semiconductors, this study was to answer the question of the stability of contacts between $\mathrm{Au}$ and $\mathrm{GaSb}$ phase. The authors of this paper used thermodynamic calculations to determine thermodynamic properties of the liquid ternary system and demonstrated that the activity of gold as well as gallium exhibit negative deviation from the Raoult's law. Recently, Manasijevic 
et al. ${ }^{[14]}$ reported the results of thermal analysis and suggested phase equilibria in the ternary Au-Ga-Sb system.

Solid phase equilibria were analyzed in the ternary AuGa-As, Au-Ga-Sb systems by Thomas and Williams. ${ }^{[15]}$ The main objective of this work was to determine which metallic phases exist in equilibrium with the III-V semiconductors. Very recently, thermodynamic assessment of the ternary Au-In-Ga system was performed by Ghasemi et al. ${ }^{[16]}$ This system is useful in the growth of Au-seeded semiconductor heterostructure and for that reason attracted more attention.

However, it seems that alloys containing gallium may find more interesting applications reaching beyond microelectronic circuits. Mouani et al. ${ }^{[17]}$ studied Au-Ga-Te system because germanium and tellurium alloys exhibit interesting optical properties. Moreover, it was found recently that gallium containing multicomponent alloys can be used in dentistry. ${ }^{[18]}$ Thus, it seems that more and more multicomponent systems of interest contain gallium as a component.

Taking into account this wide spectrum of gallium alloys applications it seems to be reasonable to gather a reliable thermodynamic description of the binary systems that allows easy prediction of higher ordered alloys. Consequently, before starting to consider multicomponent gold alloys, respective binary systems with this element should be thoroughly described. Since gallium can be used as one component, there is also a need to create thermodynamic database of binary gallium alloys which can contribute to multicomponent systems. Consequently, we analyzed recently silver-gallium ${ }^{[19]}$ and copper-gallium ${ }^{[20]}$ binary alloys. As far as the Au-Ga binary system is concerned, it was already optimized twice, but under different assumptions. The first assessment was performed in 2010 by Liu et al. ${ }^{[21]}$ who took into account the nonstoichiometry of $\beta$ and $\gamma$ phases, but assumed the heat of mixing of liquid alloys to be temperature independent. In 2011 the next assessment was published by Wang et al. ${ }^{[22]}$ who treated all intermetallic phases existing in this system as line compounds. However, in their work, they assumed that the enthalpy of mixing is temperature dependent. Both papers showed good reproduction of the experimentally determined phase diagram. To gain more insight into the properties of this particular binary system, gold-gallium binary system has been re-investigated and next optimized in this work.

\section{Literature Review}

The binary gold-gallium system includes eight phases: FCC_A1, D024, $\beta-\mathrm{Au}_{7} \mathrm{Ga}_{2}, \beta^{\prime}-\mathrm{Au}_{7} \mathrm{Ga}_{2}, \gamma-\mathrm{Au}_{7} \mathrm{Ga}_{3}, \mathrm{AuGa}$, $\mathrm{AuGa}_{2}$ and Liquid.

\subsection{Thermodynamic Data}

The enthalpy of mixing of this liquid binary system was measured by using different types of calorimeters. Using an adiabatic calorimeter Itagaki and Yazawa ${ }^{[23]}$ measured the enthalpy of mixing at $1373 \mathrm{~K}$ in the whole composition range of gallium. Predel and Stein ${ }^{[24]}$ determined the enthalpy of mixing in this liquid system by using a hightemperature calorimeter at $1423 \mathrm{~K}$ in the composition range from 0.0985 to $0.9 x_{\mathrm{Ga}}$. Gather and Blachnik ${ }^{[25]}$ reported the enthalpy of mixing at $1010 \mathrm{~K}$, which was measured by the heat flow calorimeter in the composition range from 0.551 to $0.923 x_{\mathrm{Ga}}$. Using reaction calorimeter Bergman et al. ${ }^{[26]}$ measured the enthalpy of mixing in this binary system at 830 and at $1030 \mathrm{~K}$ in the composition range from 0.15 to $0.95 x_{\mathrm{Ga}}$. The enthalpy of mixing of liquid gold-gallium alloys at several different temperatures: 774, 787, 929, 1081, 1468, 1558 and $1661 \mathrm{~K}$ in the composition range from 0.30 to $0.94 x_{\mathrm{Ga}}$ was determined by Hayer et al. ${ }^{[27]}$ using reaction calorimetry. Beja ${ }^{[28]}$ measured $\Delta_{\mathrm{Mix}} H$ at 850 and at $1030 \mathrm{~K}$ in the composition range from 0.1 to $0.8 x_{\mathrm{Ga}}$.

Recently, Jendrzejczyk-Handzlik ${ }^{[29]}$ measured the enthalpies of mixing for the liquid $\mathrm{Au}-\mathrm{Ga}$ system at two temperatures 1223 and $1323 \mathrm{~K}$, in the composition range from 0.97 to $0.356 x_{\mathrm{Ga}}$ using high-temperature drop calorimeter.

All experimental results obtained from the calorimetric method show negative values of the enthalpy of mixing in the liquid phase. The experimental data ${ }^{[25-29]}$ are compatible with one another. Experimental values reported by Itagaki and Yazawa ${ }^{[23]}$ and Predel and Stein ${ }^{[24]}$ are less negative than the values reported in studies, ${ }^{[25-29]}$ and these data were not used in the present optimization of binary gold-gallium system.

As far as the solid phases are concerned, Bergman et al. ${ }^{[26]}$ determined the enthalpy of formation of AuGa and $\mathrm{AuGa}_{2}$ at $298 \mathrm{~K}$ using calorimetry method. Predel and Stein ${ }^{[30]}$ investigated the enthalpies of formation of AuGa and $\mathrm{AuGa}_{2}$ phases at $700 \mathrm{~K}$, by using liquid tin solution calorimetry. Predel and Stein ${ }^{[24]}$ determined the enthalpy of formation of $\mathrm{fcc}(\mathrm{Au})$ phase at $703 \mathrm{~K}$ over the range of compositions $0.03-0.10$ at.\% Ga. Wallbrecht et al. ${ }^{[31]}$ measured the enthalpy increments $\left(H_{T}^{\circ}-H_{298.15}^{\circ}\right)$ and heat capacity of three compounds: $\gamma-\mathrm{Au}_{7} \mathrm{Ga}_{3}$ at the composition $\mathrm{Au}_{0.692} \mathrm{Ga}_{0.308}, \mathrm{AuGa}$ at the composition $\mathrm{Au}_{0.5} \mathrm{Ga}_{0.5}$ and $\mathrm{AuGa}_{2}$ at the composition $\mathrm{Au}_{0.34} \mathrm{Ga}_{0.66}$. Measurements were carried out using differential scanning calorimetry in the temperature range between 235 and $700 \mathrm{~K}$. The values of the enthalpies formation of $\mathrm{AuGa}$ and $\mathrm{AuGa}_{2}$ reported by Bergman et al. ${ }^{[26]}$ are more positive than those reported by Predel and Stein ${ }^{[30]}$ (the difference between them is 
about $2000 \mathrm{~J} / \mathrm{mol}$ ). The experimental data from $\operatorname{Ref} 26,30$, and 31 were taken into account in the present optimization.

The activities of $\mathrm{Au}$ and $\mathrm{Ga}$ in liquid gold-gallium system were measured at $1400 \mathrm{~K}$ by Bergman et al. ${ }^{[26]}$ who used Knudsen cell coupled with the mass spectrometer. Kameda and Azakami ${ }^{[32]}$ determined the activity of gallium in liquid Au-Ga system at 973 and $1073 \mathrm{~K}$ using e.m.f. method with liquid salt electrolyte. Predel and Schallner ${ }^{[33]}$ determined the excess Gibbs energy at $1000 \mathrm{~K}$ in liquid $\mathrm{Au}-\mathrm{Ga}$ system in the range composition from 0.2 to 0.9 at. \% Ga. This experimental data were taken into account in present optimization.

Experimental values of the activity of gallium at 973 and $1073 \mathrm{~K}$ determined by Kameda and Azakami ${ }^{[32]}$ show much more negative deviation from Raoult's law than the data of Bergman et al. ${ }^{[26]}$ Moreover, the activities of Ga in the liquid Au-Ga alloys reported in Ref 32 are independent of temperature. Due to possible exchange reaction between the alloy and molten salts, the data of Kameda and Aza$\mathrm{kami}^{[32]}$ were not used in the present optimization.

\subsection{Phase Diagram Data}

The Au-Ga system was studied first time by Weibke and Hesse $^{[34]}$ who used $\mathrm{x}$-ray, microscopic and differential thermal analysis. Next, Owen and Roberts ${ }^{[35]}$ determined the solubility of $\mathrm{Ga}$ in the $\mathrm{fcc}(\mathrm{Au})$ phase through the lattice parameter measurements, and consequently modified the solid solubility value of gallium in $\mathrm{fcc}(\mathrm{Au})$ given by Weibke and Hesse. ${ }^{[34]}$ The solubility of $\mathrm{Ga}$ in the fcc(Au) phase was also reported by Kuznetsov and Shmelev ${ }^{[12]}$ from the lattice parameter measurements and microscopic analysis in the low temperature range from 373 to $623 \mathrm{~K}$.

The most extensive study was conducted by Cooke and Hume-Rothery ${ }^{[36]}$ who determined the liquidus, solidus and invariant reactions in this binary system in the whole composition range. The compositions and temperature of the invariant reactions were also given. The solubility of $\mathrm{Ga}$ in the $\operatorname{fcc}(\mathrm{Au})$ phase determined by Owen and Roberts ${ }^{[35]}$ agrees well with the experimental data obtained by Kuznetsov and Shmelev ${ }^{[12]}$ at low temperature but is slightly larger than that obtained by Cooke and Hume-Rothery ${ }^{[36]}$ at high temperature ( $>700 \mathrm{~K})$. Recently, using $\mathrm{x}$-ray, microscopic and differential thermal analysis, Zivkovic et al. ${ }^{[37]}$ determined the liquidus and invariant reactions in this system in the composition range from 0.6707 to $x_{\mathrm{Ga}}=1$. Temperatures of the liquidus reported in this paper are lower than those given in Weibke and Hesse ${ }^{[34]}$ and Cooke and HumeRothery ${ }^{[36]}$ works. No experimental data concerning the solubility of $\mathrm{Au}$ in orthorhombic $(\mathrm{Ga})$ could be found in the published literature.

Solid intermetallic phases $\beta^{\prime}-\mathrm{Au}_{7} \mathrm{Ga}_{2}, \gamma-\mathrm{Au}_{7} \mathrm{Ga}_{3}$, and $\alpha$ $\mathrm{Au}_{7} \mathrm{Ga}$ (D024) were detected and confirmed as having the hexagonal structure of $\mathrm{Ni}_{3} \mathrm{Ti}$ type (space group $\mathrm{P} 63 \mathrm{mmc}$ ) by Cooke and Hume-Rothery. ${ }^{[36,38]}$ The stability and composition of all intermetallic compounds have been examined carefully by Cooke and Hume-Rothery ${ }^{[36]}$ who detected narrow homogeneity ranges of the intermetallic compounds $\beta-\mathrm{Au}_{7} \mathrm{Ga}_{2}$ (20.4-22.1 at.\% Ga), $\beta^{\prime}-\mathrm{Au}_{7} \mathrm{Ga}_{2}$ (21.3-23.2 at.\% Ga), $\gamma$-Au7Ga3 and $\gamma^{\prime}-\mathrm{Au}_{7} \mathrm{Ga}_{3}(29.8-31.0$ at.\% Ga). Solid phases $\mathrm{AuGa}, \mathrm{AuGa}_{2}$, whose existence was also confirmed, exhibit almost stoichiometric composition. However, the results obtained by Cooke and Hume-Rothery $^{[36]}$ are different from those which were reported by Weibke and Hesse. ${ }^{[34]}$

The structures of the stable intermetallic compounds: $\alpha$ $\mathrm{Au}_{7} \mathrm{Ga}, \quad \beta-\mathrm{Au}_{7} \mathrm{Ga}_{2}, \quad \beta^{\prime}-\mathrm{Au}_{7} \mathrm{Ga}_{2}, \quad \gamma-\mathrm{Au}_{7} \mathrm{Ga}_{3}, \quad \gamma^{\prime}-\mathrm{Au}_{7} \mathrm{Ga}_{3}$, $\mathrm{AuGa}, \mathrm{AuGa}_{2}$ were investigated experimentally by Frank, ${ }^{[39]}$ Wallace and Kitchingman ${ }^{[40]}$ and Puselj and Schubert. ${ }^{[11]}$ Order-disorder transformation between $\gamma$ $\mathrm{Au}_{7} \mathrm{Ga}_{3}$ and $\gamma^{\prime}-\mathrm{Au}_{7} \mathrm{Ga}_{3}$ was suggested by Cooke and Hume-Rothery. ${ }^{[36]}$ Due to their narrow homogeneity ranges (29.8-31.0 at.\% Ga) and unconfirmed order-disorder transition between $\gamma-\mathrm{Au}_{7} \mathrm{Ga}_{3}$ and $\gamma^{\prime}-\mathrm{Au}_{7} \mathrm{Ga}_{3}$, this phase is modeled as one compound denoted as $\gamma-\mathrm{Au}_{7} \mathrm{Ga}_{3}$. The intermetallic compounds: $\mathrm{AuGa}$ and $\mathrm{AuGa}_{2}$ due to their almost fixed composition (limited solubility $<2$ at.\%) can be considered as "line" compounds.

Experimental information mentioned above in Ref 3441 was taken into account in the present optimization, while the solubility of $\mathrm{Au}$ in Orthorhombic $(\mathrm{Ga})$ was neglected due to the lack of experimental information.

$\mathrm{Au}-\mathrm{Ga}$ phase diagram was reviewed first time by Elliott and Shumnk ${ }^{[42]}$ but the phase boundary of the Au-rich terminal solid solution phase was uncertain. Next, Mof$\mathrm{fat}^{[43]}$ and Masalski and Okamoto ${ }^{[44]}$ re-rewieved the AuGa phase diagram. Finally, Mouani et al. ${ }^{[17]}$ re-investigated the Au-Ga phase diagram during their study of the Au-GaTe system. They reported temperature of the peritectic reaction $L+\mathrm{fcc}(\mathrm{Au}) \rightarrow \alpha-\mathrm{Au}_{7} \mathrm{Ga}_{2}$ to be $696 \mathrm{~K}$. The temperature of this invariant reaction is different from the result of Cooke and Hume-Rothery ${ }^{[36]}$ which is $688 \mathrm{~K}$. Recently, Liu et al. ${ }^{[21]}$ and Wang et al. ${ }^{[22]}$ optimized Au-Ga phase diagram by means of CALPHAD (CALculation of PHase Diagrams) method.

\section{Experimental}

\subsection{Materials}

Gold rods of $5 \mathrm{~mm}$ in diameter were obtained from Mennica Polska, Poland. Iron powders, metallic gallium, tungsten wire (diameter $0.5 \mathrm{~mm}$ ) were obtained from Alfa Aesar, Germany. They were of minimum mass fractions purities $99.9999 \%$ ( $\mathrm{Au}, \mathrm{Fe})$ and $99.99 \%$ ( $\mathrm{Ga}, \mathrm{W})$. 
Gallium(III) oxide and iron(IV) oxide with the minimum mass fraction purity $99.99 \%$ were obtained from Sigma Aldrich, Germany. The gas atmosphere was pure argon obtained from Air Products, of minimum mass fraction 99.999 used for the EMF method.

Closed at one end YSZ electrolyte tubes (length $50 \mathrm{~mm}$, outside diameter $8 \mathrm{~mm}$ ) were supplied by the Yamari, Japan. Gold-gallium alloys were prepared from pure metals prior to EMF experiments. Similarly, weighed samples of about $200 \mathrm{mg}$ prepared for DTA experiments with the following compositions: $\mathrm{Au}_{0.85} \mathrm{Ga}_{0.15}, \mathrm{Au}_{0.75} \mathrm{Ga}_{0.25}$ and $\mathrm{Au}_{0.60} \mathrm{Ga}_{0.40}$ were placed inside the thin quartz tubes, and then they were sealed under vacuum. Next, the samples were annealed in the operating furnace VMK22, Linn High Therm for 4 weeks at the temperature $473 \mathrm{~K}$. After annealing they were transferred to DTA apparatus.

\subsection{EMF Technique}

A schematic representation of the cell assembly is shown and described in the previous papers. ${ }^{[19,20]}$ The working electrode was metallic alloy of a chosen composition with the addition of $\mathrm{Ga}_{2} \mathrm{O}_{3}$. The reference electrode was a mixture of $\mathrm{Fe}+\mathrm{FeO}$ which was produced by heating the mixture of $\mathrm{Fe}$ and $\mathrm{Fe}_{3} \mathrm{O}_{4}$ powders under argon up to $T=1273 \mathrm{~K}$. The cell was kept within the constant temperature zone of the furnace under a flow of purified argon. Initially, as electric lead wires tungsten wire was used. However, it was necessary to substitute it for the working electrode with kanthal wire with on attached iridium tip. The temperature inside the cell was maintained constant within $\pm 1 \mathrm{~K}$, which was achieved by using temperature controller Lumel type RE15. The EMF of the cell was recorded by means of the digital Keithley 2000 multimeter. Thanks to the program written in Delphi, EMF values were read out from the Keithley multimeter directly to the computer. Consequently, measurements were performed under very precise control of the EMF change with temperature. The measurements were carried out at increasing and decreasing temperature for three days.

\subsection{DTA Measurements}

DTA measurements were carried out on three Au-Ga alloys with the chosen composition $x_{\mathrm{Ga}}=0.15,0.25$ and 0.40 , and in the temperature range from 473 to $1300 \mathrm{~K}$. The samples of the alloys were prepared from pieces of pure elements. The weight of samples used for the experiments was about $200 \mathrm{mg}$. The measurements were performed on DTA 404 apparatus from Netzsch, Selb, Germany. This device is hooked up to PC in order to control all DTA procedures during the experiment by PROTEUS software, also obtained from Netzsch. The acquired data were recorded on PC. The total experimental error of the method has been estimated to be $\pm 1 \mathrm{~K}$. Two different heating/cooling rates 5 and $2 \mathrm{~K} / \mathrm{min}$ were used to verify the temperature of the detected phase transitions, starting from the annealing temperature up to about $323 \mathrm{~K}$ above the estimated liquidus temperature.

\section{Results}

\subsection{E.M.F.'s Method}

The gallium activity in Au-Ga system was determined by using EMF method with the cell (I) in the temperature range from 1050 to $1273 \mathrm{~K}$.

$$
\begin{aligned}
& \mathrm{W} \text { (or Kanthal }+\mathrm{Ir} \text { ), } \mathrm{Au}_{x} \mathrm{Ga}_{(1-x)}, \mathrm{Ga}_{2} \mathrm{O}_{3} / / \mathrm{ZrO}_{2} \\
& \quad+\left(\mathrm{Y}_{2} \mathrm{O}_{3}\right) / / \mathrm{FeO}, \mathrm{Fe}, \mathrm{W}
\end{aligned}
$$

the overall reaction cell (I) is:

$3 \mathrm{FeO}+2 \underline{\mathrm{Ga}}=\mathrm{Ga}_{2} \mathrm{O}_{3}+3 \mathrm{Fe}$

For the reversible reaction $(\mathrm{Eq} 1)$, the change in Gibbs free energy can be derived as follows:

$\Delta_{r} G=-6 F E=\Delta_{f} G_{m, \mathrm{Ga}_{2} \mathrm{O}_{3}}^{\circ}-3 \Delta_{f} G_{m, \mathrm{Feo}}^{\circ}-2 R T \ln a_{\mathrm{Ga}}$

If gallium is in its pure, liquid state $\left(a_{\mathrm{Ga}}=1.0\right) \mathrm{Eq} 2$ takes the form:

$-6 F E^{\circ}=\Delta_{f} G_{m, \mathrm{Ga}_{2} \mathrm{O}_{3}}^{\circ}-3 \Delta_{f} G_{m, \mathrm{FeO}}^{\circ}$

from which one can determine the change of Gibbs free energy of the reaction of formation of pure solid $\mathrm{Ga}_{2} \mathrm{O}_{3}$ :

$\Delta_{f} G_{m, \mathrm{Ga}_{2} \mathrm{O}_{3}}^{\circ}=-6 F E^{\circ}+3 \Delta_{f} G_{m, \mathrm{FeO}}^{\circ}$

Thus, from Eq 4 the Gibbs free energy of formation of the solid $\mathrm{Ga}_{2} \mathrm{O}_{3}, \Delta G_{m, \mathrm{Ga}_{2} \mathrm{O}_{3}}^{\circ}$ can be determined from $E^{\circ}$ measured as a function of temperature against the $\mathrm{Fe}, \mathrm{FeO}$ reference electrode.

The values of Gibbs free energy are described by the following temperature dependence:

$\Delta G_{m, \mathrm{Ga}_{2} \mathrm{O}_{3}}^{\circ}( \pm 4) / \mathrm{kJ} / \mathrm{mol}=-1049.02+0.2807(T / \mathrm{K})$

The data, given by Eq 5, were compared with the data already published in the literature. ${ }^{[19,20]}$ The spread between the results reported in different studies is of the order of $30 \mathrm{~kJ}$, which is about $3 \%$ of the measured value. On this basis, one can conclude that present results are in good agreement with those already published.

E.m.f. values produced by the cell(I) and corrected for thermo-emf's, are shown in Fig. 1. The resulting linear 


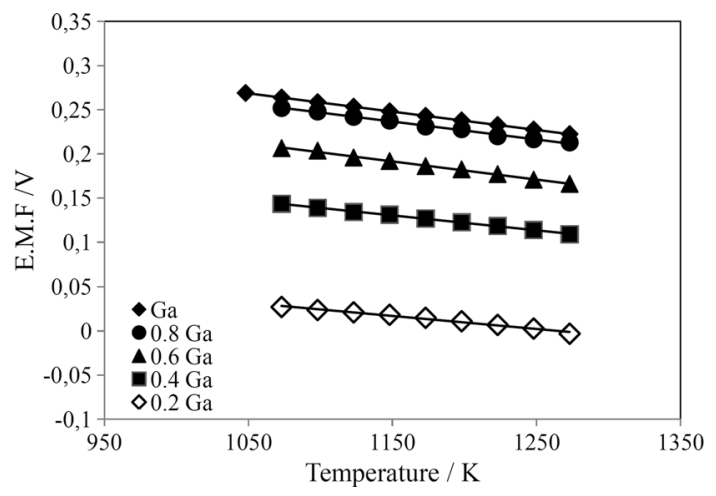

Fig. 1 Temperature dependence of the EMF

equations obtained by the least square method, are presented in Table 1.

Next, by combining Eq 2 and 3 the following expression for the activity of gallium in the alloy with copper can be derived:

$\ln a_{\mathrm{Ga}}=\frac{3 F}{R T}\left(E-E^{\circ}\right)$

where $F$ is the Faraday constant, $T$ is the absolute temperature and $R$ is the gas constant.

Finally, from the measured EMF's, the expression for the partial Gibbs free energy of gallium in the alloy can be easily derived:

$\Delta \bar{\mu}_{\mathrm{Ga}}=R T \ln a_{\mathrm{Ga}}=3 F\left(E-E^{\circ}\right)=3 F(\Delta a+\Delta b(T / K))$

if the linear dependence of the type $a+b T$ is assumed for temperature variation of the EMF.

As an example, the activity of gallium in the Au-Ga alloys was calculated at 1273 and $1400 \mathrm{~K}$ and it is shown in Fig. 2 as a function of Ga mole fraction. These values are in good agreement with the results of Bergman et al. ${ }^{[26]}$ who used high temperature Knudsen cell coupled with the mass spectrometer.

\subsection{DTA Study}

DTA curves recorded for three compositions $x_{\mathrm{Ga}}=0.15$, 0.25 and 0.40 are shown in Fig. 3 and 4. For compositions of alloys having mole fractions $x_{\mathrm{Ga}}=0.25$ and 0.4 , the experiments were run with the rate $5 \mathrm{~K} / \mathrm{min}$ and they showed clearly temperatures of invariant reactions and liquidus. For the sample with 0.15 mole fraction of gallium, the experiments were run with the rate $5 \mathrm{~K} / \mathrm{min}$ to reveal temperature of liquidus and $2 \mathrm{~K} / \mathrm{min}$ to better expose the temperature of invariant reactions. The obtained results of DTA analysis are gathered in Table 2.
Table 1 The temperature dependence of the EMF of cell (I)

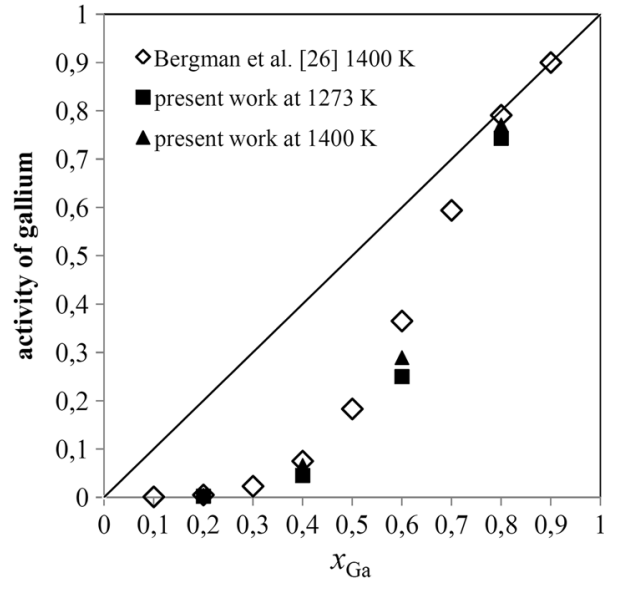

Fig. 2 Activity of gallium in the liquid Au-Ga system, standard state pure liquid metals

\section{Thermodynamic Modelling}

\subsection{Substitutional Solution: FCC_A1, D024, Orthorombic_Ga, Liquid}

The substitutional solution model was assumed to be applicable to FCC_A1, D024, Orthorombic_Ga solid phases as well as to the liquid phase.The Gibbs free energy of pure elements with respect to temperature ${ }^{\circ} G_{i}^{\phi}(T)=$ $G_{i}^{\phi}(T)-H_{i}^{\mathrm{SER}}(T)(298.15 K)$ for the element $i(\mathrm{i}=\mathrm{Au}$, Ga) in $\phi$ ( $\phi=$ liquid, fcc, D024 and Ortorombic_Ga) is represented by Eq 8 :

$$
\begin{aligned}
{ }^{\circ} G_{i}^{\phi}(T)= & a+b T+c T \ln b(T)+d T^{2}+e T^{-1}+f T^{3} \\
& +i T^{4}+j T^{7}+k T^{-9}
\end{aligned}
$$

The ${ }^{\circ} G_{i}^{\phi}(T)$ data are referred to the constant enthalpy value of the standard element reference $H_{i}^{\mathrm{SER}}$ at $298.15 \mathrm{~K}$ and 1 bar as recommended by Scientific Group Thermodata Europe (SGTE). ${ }^{[45]}$ The reference states are: FCC_A1 (Au), and Orthorombic_Ga (Ga). The ${ }^{\circ} G_{i}^{\phi}(T)$ expression may be given for several temperature ranges, where the 
Fig. 3 DTA heating $5 \mathrm{~K} / \mathrm{min}$ curve of $x_{\mathrm{Ga}}=0.4,0.25,0.15$

Fig. 4 DTA heating $2 K / m i n$ curve of $x_{\mathrm{Ga}}=0.15$

Table 2 Summary of measured thermal effects
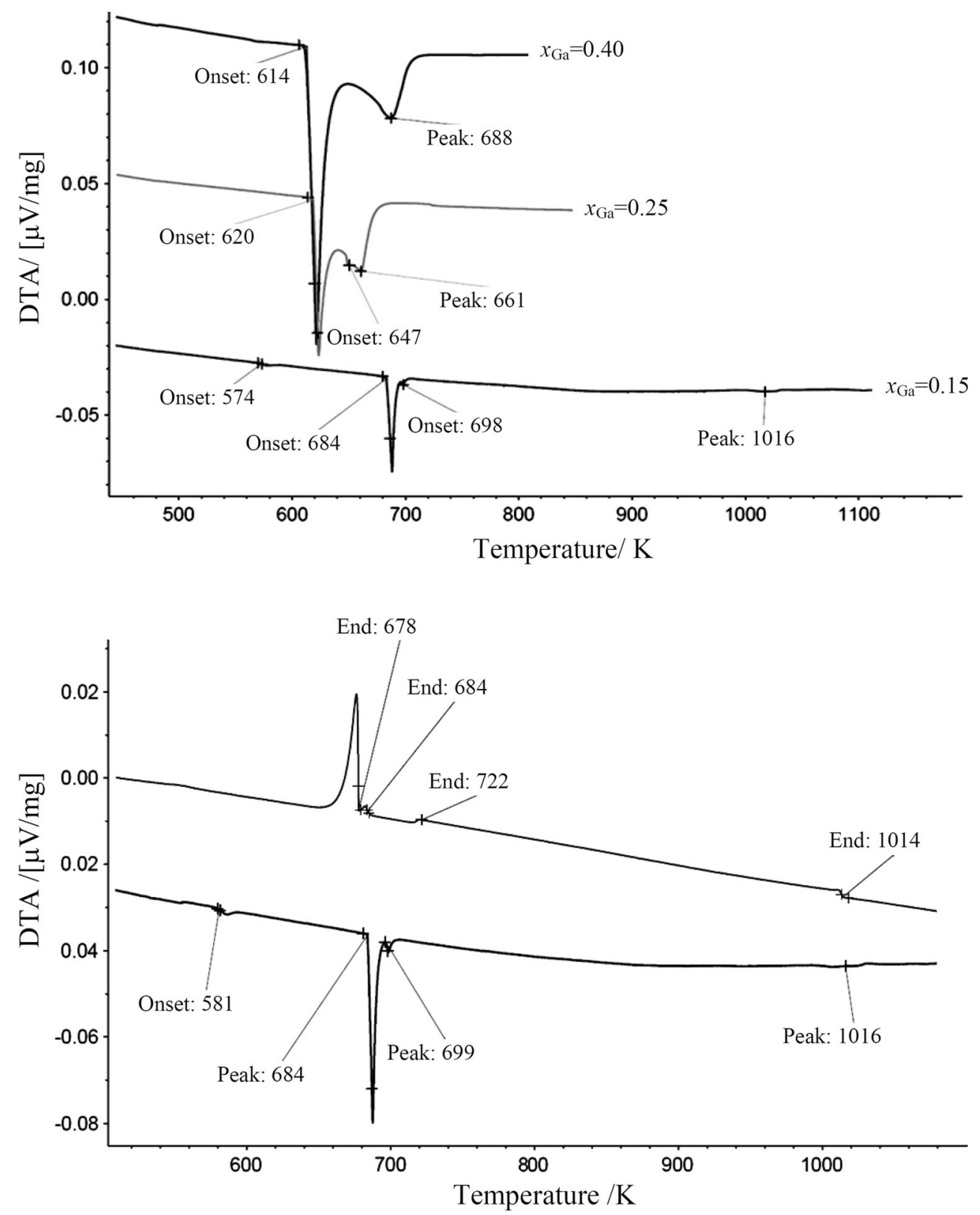

\begin{tabular}{|c|c|c|c|}
\hline \multirow[t]{3}{*}{ Sample comp. $/ x_{\mathrm{Ga}}$} & \multirow[t]{3}{*}{ Type reaction } & \multicolumn{2}{|c|}{ Thermal analysis } \\
\hline & & \multicolumn{2}{|c|}{ Heating/K } \\
\hline & & Invariant effects & Liquidus \\
\hline 0.4 & $L \leftrightarrow \gamma-\mathrm{Au}_{7} \mathrm{Ga}_{3}+\mathrm{AuGa}$ & 613 & 688 \\
\hline 0.25 & $L \leftrightarrow \gamma-\mathrm{Au}_{7} \mathrm{Ga}_{3}+\beta^{\prime}-\mathrm{Au}_{7} \mathrm{Ga}_{2}$ & 620 & 661 \\
\hline & $L+\beta-\mathrm{Au}_{7} \mathrm{Ga}_{2} \leftrightarrow \beta^{\prime}-\mathrm{Au}_{7} \mathrm{Ga}_{2}$ & 647 & \\
\hline 0.15 & $\beta-\mathrm{Au}_{7} \mathrm{Ga}_{2} \leftrightarrow \mathrm{fcc}(\mathrm{Au})+\beta^{\prime}-\mathrm{Au}_{7} \mathrm{Ga}_{2}$ & 581 & 1017 \\
\hline & $L+\mathrm{D} 024 \leftrightarrow \beta-\mathrm{Au}_{7} \mathrm{Ga}_{2}$ & 684 & \\
\hline & $L+\mathrm{fcc}(\mathrm{Au}) \leftrightarrow \mathrm{D} 024$ & 697 & \\
\hline
\end{tabular}

Underlined: heating $5 \mathrm{~K} / \mathrm{min}$ 
Table 3 Thermodynamic parameters of Au-Ga system

\begin{tabular}{|c|c|c|c|}
\hline \multirow[t]{2}{*}{ Phase } & \multicolumn{2}{|r|}{ Thermodynamic parameters, $\mathrm{J} / \mathrm{mol}$} & \multirow[t]{2}{*}{ Ref } \\
\hline & $T, \mathrm{~K}$ & Function & \\
\hline \multirow[t]{6}{*}{$\mathrm{Au}$} & 298.15-929.4 & $\begin{array}{l}\text { GHSERAU }=-6938.856+106.830098 T-22.75455 T \ln (T) \\
-3.85924 T^{2}+0.37962 \times 10^{-6} T^{3}-25097 T^{3}-25097 T^{-1}\end{array}$ & \multirow[t]{6}{*}{ Ref 45} \\
\hline & $929.4-1337.3$ & $-93,586.481+1021.69543 T-155.7067449 T \ln (\mathrm{T})+87.56015$ & \\
\hline & & $\times 10^{-3} T^{2}-11.518713 \times 10^{-6} T^{3}+10637210 T^{-1}$ & \\
\hline & $1337.3-1735.8$ & $+314,067.829-2016.378254 T+263.2522592 T \ln (T)-118.216828$ & \\
\hline & & $\times 10^{-3} T^{2}+8.923844 \times 10^{-6} T^{3}-67999832 T^{-1}$ & \\
\hline & $1735.8-3200$ & $-12,133.783+165.272524 T-30.9616 T \ln (T)$ & \\
\hline \multirow[t]{3}{*}{$\mathrm{Ga}$} & 200.0-302.9 & $\begin{array}{l}\text { GHSERGA }=+21,312.331+585.263691 T-108.2287832 T \ln (T) \\
+227.155636 \times 10^{-3} T^{2}-118.575257 \times 10^{-6} T^{3}+439954 T^{-1}\end{array}$ & \multirow[t]{3}{*}{ Ref 45} \\
\hline & $302.9-4000$ & $-7055.643+132.73019 T-26.0692906 T \ln (T)+0.1506$ & \\
\hline & & $\times 10^{-3} T^{-2}-0.040173 \times 10^{-6} T^{3}-118332 T^{-1}$ & \\
\hline \multirow[t]{9}{*}{ Liquid } & 298.15-929.4 & $\begin{array}{l}{ }^{\circ} G_{\text {Au }}^{\text {liquid }}=+5613.144+97.444232 T-22.75455 T \ln (T) \\
-0.00385924 T^{2}+3.79625 \times 10^{-7} T^{3}-25097 T^{-1}\end{array}$ & \multirow[t]{4}{*}{ Ref 45} \\
\hline & $929.4-1337.3$ & $\begin{array}{l}-81,034.481+1012.30956 T-155.706745 T \ln (T) \\
+0.08756015 T^{2}-1.1518713 \times 10^{-5} T^{3}+10637210 T^{-1}\end{array}$ & \\
\hline & $1337.3-1735.8$ & $\begin{array}{l}+326,619.829-2025.76412 T+263.252259 T \ln (T) \\
-0.118216828 T^{2}+8.923844 \times 10^{-6} T^{3}-67999832 T^{-1}\end{array}$ & \\
\hline & $1735.8-3200$ & $+418.217+155.886658 T-30.9616 T \ln (T)$ & \\
\hline & 200.0-302.9 & $\begin{array}{l}{ }^{\circ} G_{\mathrm{Ga}}^{\text {liquid }}=-15,821.033 \\
+567.189696 T-108.228783 T \ln (T)+0.227155636 T^{2} \\
-1.18575257 \times 10^{-4} T^{3}+439954 T^{-1}-7.0171 \times 10^{-17} T^{7}\end{array}$ & \multirow[t]{2}{*}{ Ref 45} \\
\hline & $302.9-4000.0$ & $\begin{array}{l}-1389.188+114.049043 T-26.0692906 T \ln (T) \\
+1.506 \times 10^{-4} T^{2}-4.0173 \times 10^{-8} T^{3}-118332 T^{-1}\end{array}$ & \\
\hline & & ${ }^{\circ} L^{\mathrm{Liq}}=-64,836.418-1.669 T$ & \multirow[t]{3}{*}{ This work } \\
\hline & & ${ }^{1} L^{\mathrm{Liq}}=-26,517.288+8.315 T$ & \\
\hline & & ${ }^{2} L^{\mathrm{Liq}}=-12,480.212+14.248 T$ & \\
\hline \multirow[t]{5}{*}{$\mathrm{fcc}(\mathrm{Au})$} & 298.14-3200 & ${ }^{\circ} G_{\mathrm{Au}}^{\mathrm{fcc}}=+$ GHSERAU & Ref 45 \\
\hline & $200.0-302.91$ & $\begin{array}{l}{ }^{\circ} G_{\mathrm{Ga}}^{\mathrm{fcc}}=-17,512.331+575.063691 T-108.228783 T \ln (T) \\
+0.227155636 T^{2}-1.18575257 \times 10^{-4} T^{3}+439954 T^{-1}\end{array}$ & \multirow[t]{2}{*}{ Ref 45} \\
\hline & $302.91-4000$ & $\begin{array}{l}-3255.643+122.53019 T-26.0692906 T \ln (T) \\
+1.506 \times 10^{-4} T^{2}-4.0173 \times 10^{-8} T^{3}-118332 T^{-1}+1.64547 \times 10^{23} T^{-9}\end{array}$ & \\
\hline & & ${ }^{\circ} L^{\mathrm{fcc}}=-39,175.271-9.981 T$ & \multirow[t]{2}{*}{ This work } \\
\hline & & ${ }^{1} L^{\mathrm{fcc}}=-9422.717$ & \\
\hline \multirow[t]{2}{*}{ Orthorombic $(\mathrm{Ga})$} & & ${ }^{\circ} G_{\mathrm{Au}}^{\text {Ort. }}=+$ GHSERAU +5000 & Ref 45 \\
\hline & & ${ }^{\circ} G_{\mathrm{Ga}}^{\text {Ort. }}=+$ GHSERGA & Ref 45 \\
\hline \multirow[t]{4}{*}{ D024 } & & ${ }^{\circ} G_{\mathrm{Au}}^{\mathrm{D} 024}={ }^{\circ} G_{\mathrm{Au}}^{\mathrm{fcc}}+125+0.79 T$ & Ref 48,49 \\
\hline & & ${ }^{\circ} G_{\mathrm{Ga}}^{\mathrm{D} 024}={ }^{\circ} \mathrm{G}_{\mathrm{Ga}}^{\mathrm{hcp}}={ }^{\circ} \mathrm{G}_{\mathrm{Ga}}^{\mathrm{Ort}}+4500-9.5 T$ & Ref 45 \\
\hline & & ${ }^{\circ} L^{\mathrm{D} 024}=-41,254.465-10.662 T$ & \multirow[t]{2}{*}{ This work } \\
\hline & & ${ }^{1} L^{\mathrm{D} 024}=-14,732.616$ & \\
\hline$\beta-\mathrm{Au}_{7} \mathrm{Ga}_{2}$ & & ${ }^{\circ} G_{m}^{\beta-\mathrm{Au}_{7} \mathrm{Ga}_{2}}=0.78950^{\circ} G_{\mathrm{Au}}^{\mathrm{fcc}}+0.21050^{\circ} G_{\mathrm{Ga}}^{\mathrm{Ort.}}-10903.861-2.673 T$ & This work \\
\hline$\beta^{\prime}-\mathrm{Au}_{7} \mathrm{Ga}_{2}$ & & ${ }^{\circ} G_{m}^{\beta^{\prime}-\mathrm{Au}_{7} \mathrm{Ga}_{2}}=0.77770^{\circ} G_{\mathrm{Au}}^{\mathrm{fcc}}+0.22230^{\circ} G_{\mathrm{Ga}}^{\mathrm{Ort}}-12,318.231-1.276 T$ & This work \\
\hline$\gamma-\mathrm{Au}_{7} \mathrm{Ga}_{2}$ & & ${ }^{\circ} G_{m}^{\gamma-\mathrm{Au}_{7} \mathrm{Ga}_{3}}=0.70^{\circ} G_{\mathrm{Au}}^{\mathrm{fcc}}+0.30^{\circ} G_{\mathrm{Ga}}^{\mathrm{Ort}}-16,793.819+1.314 T$ & This work \\
\hline AuGa & & ${ }^{\circ} G_{m}^{\mathrm{AuGa}}=0.50^{\circ} G_{\mathrm{Au}}^{\mathrm{fcc}}+0.50^{\circ} G_{\mathrm{Ga}}^{\text {Ort. }}-20,815.031-1.528 T$ & This work \\
\hline $\mathrm{AuGa}_{2}$ & & ${ }^{\circ} G_{m}^{\mathrm{AuGa}_{2}}=0.3333^{\circ} G_{\mathrm{Au}}^{\mathrm{fcc}}+0.6667^{\circ} G_{\mathrm{Ga}}^{\mathrm{Ort} .}-21,839.222+0.778 T$ & This work \\
\hline
\end{tabular}


Fig. 5 Calculated phase diagram of Au-Ga system superimposed with experimental data

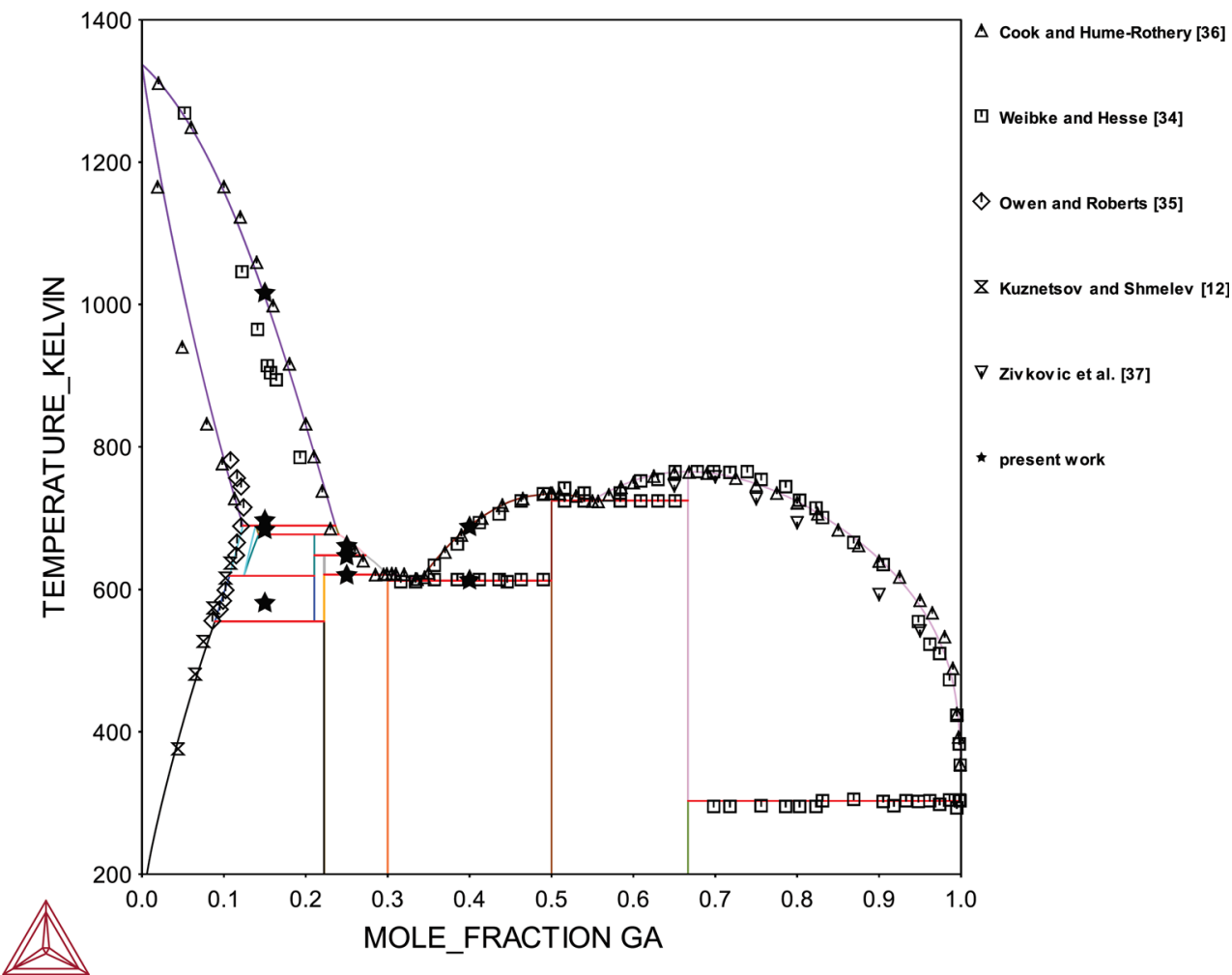

coefficients $a, b, c, d, e, f, i, j, k$ have different values. The ${ }^{\circ} G_{i}^{\phi}(T)$ functions are taken from SGTE Unary (Pure elements) TDB v.5. ${ }^{[45]}$ The Gibbs energy of the element $i$, $G_{i}^{\phi}(T)$, in its SER state is denoted by $\operatorname{GHSER}_{i}$, i.e. where $i=(\mathrm{Au}, \mathrm{Ga})$. The GHSERAU and GHSERGA are Gibbs energies of gold and gallium in FCC_A1 and Orthorhombic_Ga structures, respectively.

The thermodynamic functions of pure elements are listed in Table 3. Solid and liquid solution phases are described by the substitutional solution model: ${ }^{[46]}$

$$
\begin{aligned}
G_{m}^{\phi}= & x_{\mathrm{Au}} G_{\mathrm{Au}}^{\phi}(T)+x_{\mathrm{Ga}} G_{\mathrm{Ga}}^{\phi}(T)+R T\left(x_{\mathrm{Au}} \ln x_{\mathrm{Au}}\right. \\
& \left.+x_{\mathrm{Ga}} \ln x_{\mathrm{Ga}}\right)+x_{\mathrm{Au}} x_{\mathrm{Ga}} \sum_{j}^{j} L^{\phi}\left(x_{\mathrm{Au}}-x_{\mathrm{Ga}}\right)^{j}
\end{aligned}
$$

where $x_{\mathrm{Au} \text { and }} x_{\mathrm{Ga}}$ are the mole fractions of $\mathrm{Au}$ and $\mathrm{Ga}, \phi$ is the phase (liquid, FCC_A1, D024, Orthorombic_Ga) and $j=0,1,2$. The $x_{\mathrm{Au}} x_{\mathrm{Ga}} \sum_{j}{ }^{j} L^{\phi}\left(x_{\mathrm{Au}}-x_{\mathrm{Ga}}\right)^{j}$ term is the Redlich-Kister ${ }^{[47]}$ polynomial used to describe excess Gibbs free energy. Taking into account negligible solubility of gold in pure solid gallium, the phase Orthorombic_Ga was treated as a pure element.

The molar Gibbs energy of the pure elements $\mathrm{Au}$ and $\mathrm{Ga}$ with the structure D024, ${ }^{\circ} G_{\mathrm{Au}}^{\mathrm{D} 024}(T)$ and ${ }^{\circ} G_{\mathrm{Ga}}^{\mathrm{D} 024}(T)$ is not given in the Scientific Group Thermodata Europe (SGTE) database. ${ }^{[45]}$ In the present work, because the crystal structure of the D024 phase is similar to the hexagonal close packed structure (hcp structure), ${ }^{\circ} G_{\mathrm{G} a}^{\mathrm{D} 024}(T)$ is assumed to be equal to, ${ }^{\circ} G_{\mathrm{Ga}}^{\mathrm{hcp}}(T)$ i.e. ${ }^{\circ} G_{\mathrm{Ga}}^{\mathrm{D} 024}(T)=$ ${ }^{\circ} G_{\mathrm{Ga}}^{\mathrm{hcp}}(T)=+4500-9.5 T \mathrm{~J} / \mathrm{mol}$. In turn, ${ }^{\circ} G_{\mathrm{Au}}^{\mathrm{D} 024}(T)$ was reported by Liu et al. ${ }^{[48,49]}$ in the assessments of the Au-In and $\mathrm{Au}-\mathrm{In}-\mathrm{Sn}$ systems.

\subsection{Intermetallic Compounds}

In the $\mathrm{Au}-\mathrm{Ga}$ binary system, five intermetallic compounds: $\beta-\mathrm{Au}_{7} \mathrm{Ga}_{2}, \beta^{\prime}-\mathrm{Au}_{7} \mathrm{Ga}_{2}, \gamma-\mathrm{Au}_{7} \mathrm{Ga}_{3}, \mathrm{AuGa}$ and $\mathrm{AuGa}_{2}$, are treated as stoichiometric compounds $\left(\mathrm{Au}_{\mathrm{x}} \mathrm{Ga}_{\mathrm{y}}\right)$ because of their narrow homogeneity ranges as determined by Cooke and Hume-Rothery. ${ }^{[36]}$

- AuGa has a structure of the $\mathrm{MnP}(\mathrm{B} 31)$-type, ${ }^{[11,14,31]}$

- $\mathrm{AuGa}_{2}$ has isotypic $\mathrm{CaF} 2(\mathrm{C} 1)$-type structure, ${ }^{[38,41,50]}$

- $\beta-\mathrm{Au}_{7} \mathrm{Ga}_{2}$ has a hexagonal structure ${ }^{[39,41]}$ and extends from $\sim 20.4$ to 22.1 at.\% $\mathrm{Ga},{ }^{[17,36]}$

- $\quad \beta^{\prime}-\mathrm{Au}_{7} \mathrm{Ga}_{2}$ is formed peritectically at $682.8 \mathrm{~K}$ and exists unchanged down to room temperature. It has an orthorhombic structure $^{[36]}$ and has a homogeneity range between 21.3 and 24.8 at.\% $\mathrm{Ga}{ }^{[17,36,44]}$

- $\gamma-\mathrm{Au}_{7} \mathrm{Ga}_{3}$ has orthorhombic structure. ${ }^{[36,44]}$

All binary stoichiometric compounds $\mathrm{Au}_{\mathrm{x}} \mathrm{Ga}_{\mathrm{y}}$ were described as the line compounds using the following expression: 
Table 4 Invariant reactions in the Au-Ga system

\begin{tabular}{|c|c|c|c|}
\hline Invariant reaction & Type & $T, \mathrm{~K}$ & Ref \\
\hline \multirow[t]{6}{*}{$L+\mathrm{fcc}(\mathrm{Au}) \leftrightarrow \mathrm{D} 024$} & \multirow[t]{6}{*}{ Peritectic } & 688 & Ref 36 \\
\hline & & 696 & Ref 17 \\
\hline & & 696 & Ref 21 \\
\hline & & 693 & Ref 22 \\
\hline & & 697 & This work-DTA method \\
\hline & & 690 & This work-calculated \\
\hline \multirow[t]{6}{*}{$L+\mathrm{D} 024 \leftrightarrow \beta-\mathrm{Au}_{7} \mathrm{Ga}_{2}$} & \multirow[t]{6}{*}{ Peritectic } & 683 & Ref 36 \\
\hline & & 683 & Ref 17 \\
\hline & & 683 & Ref 21 \\
\hline & & 679 & Ref 22 \\
\hline & & 684 & This work-DTA method \\
\hline & & 678 & This work-calculated \\
\hline \multirow[t]{5}{*}{$L+\beta-\mathrm{Au}_{7} \mathrm{Ga}_{2} \leftrightarrow \beta^{\prime}-\mathrm{Au}_{7} \mathrm{Ga}_{2}$} & \multirow[t]{5}{*}{ Peritectic } & 648 & Ref 36 \\
\hline & & 648 & Ref 21 \\
\hline & & 644 & Ref 22 \\
\hline & & 647 & This work-DTA method \\
\hline & & 648 & This work-calculated \\
\hline \multirow[t]{5}{*}{$L \leftrightarrow \gamma-\mathrm{Au}_{7} \mathrm{Ga}_{3}+\beta^{\prime}-\mathrm{Au}_{7} \mathrm{Ga}_{2}$} & \multirow[t]{5}{*}{ Eutectic } & 620 & Ref 36 \\
\hline & & 622 & Ref 21 \\
\hline & & 623 & Ref 22 \\
\hline & & 620 & This work-DTA method \\
\hline & & 621 & This work-calculated \\
\hline \multirow[t]{4}{*}{$L \leftrightarrow \gamma-\mathrm{Au}_{7} \mathrm{Ga}_{3}$} & \multirow[t]{4}{*}{ Congruent } & 623 & Ref 36 \\
\hline & & 622 & Ref 21 \\
\hline & & 624 & Ref 22 \\
\hline & & 621 & This work-calculated \\
\hline \multirow[t]{5}{*}{$L \leftrightarrow \gamma-\mathrm{Au}_{7} \mathrm{Ga}_{3}+\mathrm{AuGa}$} & \multirow[t]{5}{*}{ Eutectic } & 613 & Ref 36 \\
\hline & & 619 & Ref 21 \\
\hline & & 619 & Ref 22 \\
\hline & & 613 & This work-DTA method \\
\hline & & 613 & This work-calculated \\
\hline \multirow[t]{4}{*}{$L \leftrightarrow \mathrm{AuGa}$} & \multirow[t]{4}{*}{ Congruent } & 735 & Ref 36 \\
\hline & & 735 & Ref 21 \\
\hline & & 732 & Ref 22 \\
\hline & & 734 & This work-calculated \\
\hline \multirow[t]{4}{*}{$L \leftrightarrow \mathrm{AuGa}+\mathrm{AuGa}_{2}$} & \multirow[t]{4}{*}{ Eutectic } & 722 & Ref 36 \\
\hline & & 727 & Ref 21 \\
\hline & & 726 & Ref 22 \\
\hline & & 724 & This work-calculated \\
\hline \multirow[t]{4}{*}{$L \leftrightarrow \mathrm{AuGa}_{2}$} & \multirow[t]{4}{*}{ Congruent } & 764 & Ref 36 \\
\hline & & 764 & Ref 21 \\
\hline & & 764 & Ref 22 \\
\hline & & 764 & This work-calculated \\
\hline \multirow[t]{4}{*}{$L \leftrightarrow \mathrm{AuGa}_{2}+(\mathrm{Ga})$} & \multirow[t]{4}{*}{ Eutectic } & 303 & Ref 36 \\
\hline & & 303 & Ref 21 \\
\hline & & 303 & Ref 22 \\
\hline & & 303 & This work-calculated \\
\hline
\end{tabular}


Table 4 continued

\begin{tabular}{llll}
\hline Invariant reaction & Type & $T, \mathrm{~K}$ & \multicolumn{1}{c}{ Ref } \\
\hline $\mathrm{D} 024 \leftrightarrow \mathrm{fcc}(\mathrm{Au})+\beta-\mathrm{Au}_{7} \mathrm{Ga}_{2}$ & Eutectoid & 621 & Ref 36 \\
& & 621 & $\operatorname{Ref} 21$ \\
& & 621 & Ref 22 \\
$\beta-\mathrm{Au}_{7} \mathrm{Ga}_{2} \leftrightarrow \mathrm{fcc}(\mathrm{Au})+\beta^{\prime}-\mathrm{Au}_{7} \mathrm{Ga}_{2}$ & Eutectoid & 619 & This work-calculated \\
& & 555 & Ref 36 \\
& & 555 & Ref 21 \\
& & 557 & Ref 22 \\
& & 581 & This work-DTA method \\
& & 555 & This work-calculated \\
\hline
\end{tabular}

Fig. 6 Calculated activities of $\mathrm{Ga}$ in the liquid Au-Ga system and comparison with the experimental data, standard state pure liquid metals

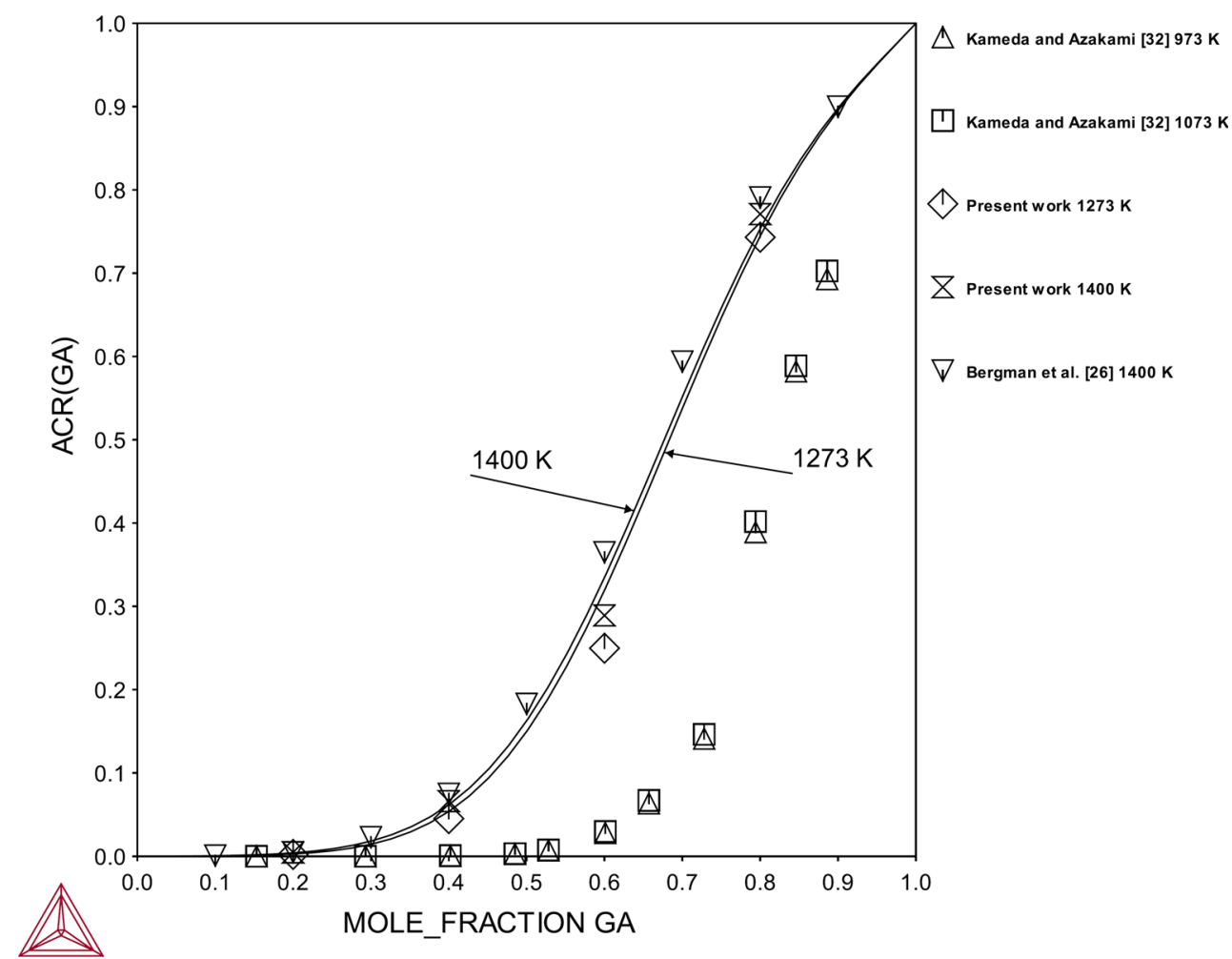

$G_{m}^{\mathrm{Au}_{x} \mathrm{Ga}_{y}}=\frac{a}{a+b}{ }^{\circ} G_{\mathrm{Au}}^{\mathrm{fcc}}+\frac{b}{a+b}{ }^{\circ} G_{\mathrm{Ga}}^{\mathrm{Ort}}+C+D \times T$

where a and $\mathrm{b}$ are ratios of stechiometry, the $C$ and $D$ are adjustable parameters to be optimized, $T$ temperature and ${ }^{\circ} G_{\mathrm{Au}}^{\mathrm{fcc}}$ and ${ }^{\circ} G_{\mathrm{Ga}}^{\mathrm{Ort}}$ are Gibbs energies of elements in their reference state.

\section{Optimization Procedure}

The thermodynamic parameters for all phases existing in the binary system were optimized using ThermoCalc software ${ }^{[51]}$ For this optimization, thermodynamic data for the liquid and solid phases, invariant reactions and liquidus/solidus were used, and optimization was done according to Schmid-Fetzer et al. ${ }^{[52]}$ guideline, similarly to previous works. ${ }^{[19,20,53,54]}$ Each piece of the selected information was given a certain weight based on experimental uncertainty. The optimization was carried out step by step. First, the optimization of the liquid phase was performed, and then the solid phases were assessed. All parameters were finally evaluated together to provide the best description of the system. The calculated interaction parameters are gathered and shown in Table 3.

\section{Results and Discussion}

The calculated Au-Ga phase diagram superimposed with experimental data obtained by Weibke and Hesse, ${ }^{[34]}$ Owen and Roberts, ${ }^{[35]}$ Cooke and Home-Rothery, ${ }^{[36]}$ 
Fig. 7 Calculated enthalpies of mixing of liquid in the Au-Ga system and comparison with experimental data, standard state pure liquid metals

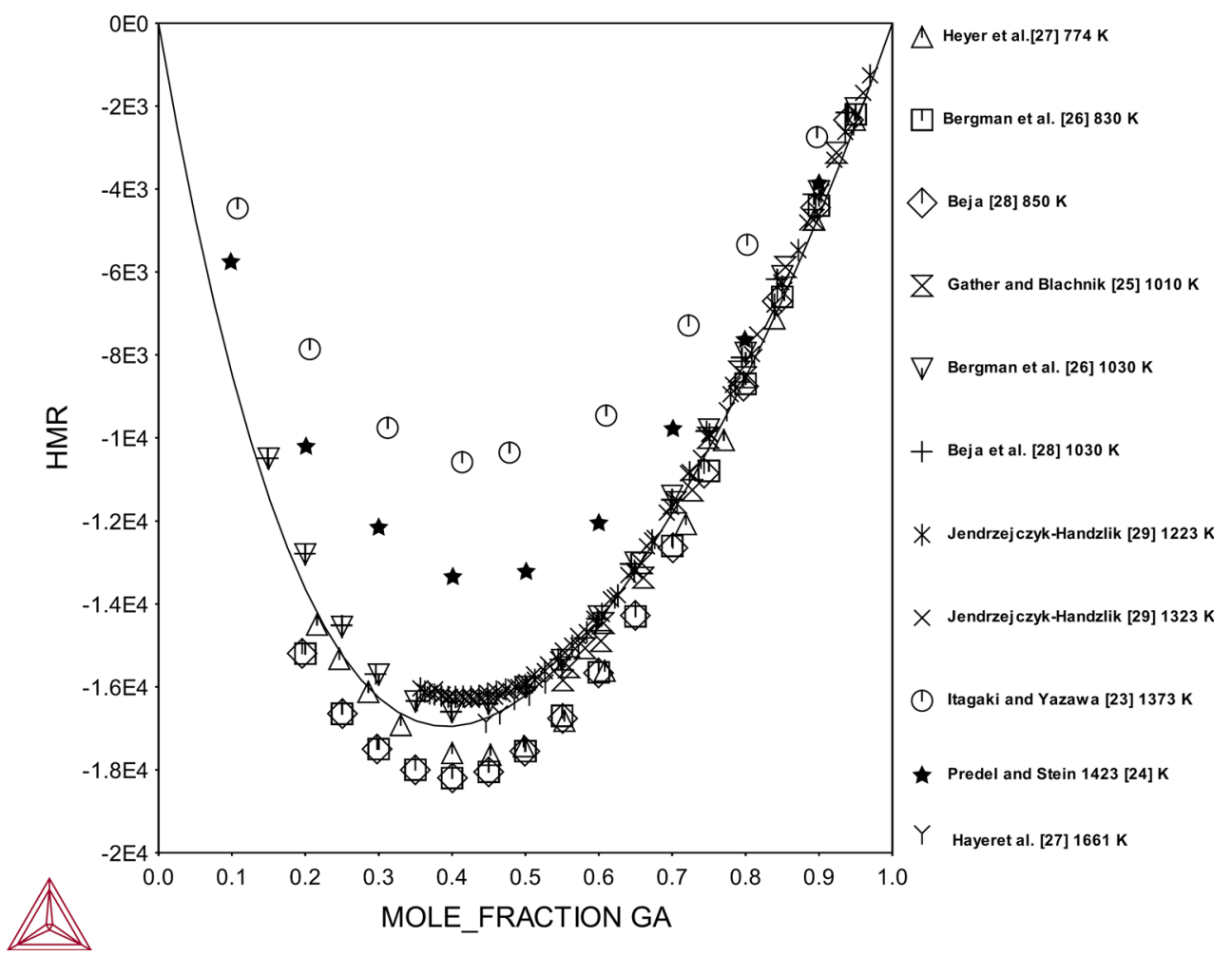

Kuznetsov and Shmelev ${ }^{[12]}$ is shown in Fig. 5. It is seen from this figure that calculated phase diagram is in very good agreement with the experimental data, except for several data points Weibke and Hesse ${ }^{[34]}$ in the Au-rich part and Zivkovic et al. ${ }^{[37]}$ in the Ga-rich part.

Based on the heating curves obtained in the present work from differential thermal analysis, temperature of liquidus and invariant reactions were determined for $x_{\mathrm{Ga}}=0.15,0.25$ and 0.4 mole fraction. The calculated and measured information about invariant reactions are gathered in Table 4. It is seen again, that the results obtained in the present work are in very good agreement with the literature data Ref 36 and the results of calculations.

Thermodynamic properties of the liquid Au-Ga solutions were determined in the present work using solid oxide galvanic cells in the temperature range from 1050 to $1273 \mathrm{~K}$. The electrochemical cells with YSZ solid electrolyte worked reversibly for three days with no sign of any side reaction. Reproducibility of the cell performance was checked by running experiments in cooling and heating cycles. From time to time a small current was passed through the cell at constant temperature. The e.m.f. returned always to the initial value in several minutes. These tests confirmed reproducible cell operation and speak for the lack of side reactions. The activity of gallium at 1273 and $1400 \mathrm{~K}$ derived from e.m.f. values was used for the description of thermodynamic properties of the liquid solutions. The activities of gallium in liquid Au-Ga alloys, which are obtained in present work, show negative deviation from Raoult's low which decreases with rising temperature.

Fig. 6 shows the calculated activity of gallium in the liquid Au-Ga alloys at 1273 and $1400 \mathrm{~K}$ obtained in present work together with the experimental data of Bergman et al. ${ }^{[26]}$ at $1400 \mathrm{~K}$. The values of gallium activity obtained at $T=1400 \mathrm{~K}$ are in good agreement with Bergman at al. ${ }^{[26]}$ for $x_{\mathrm{Ga}}=0.8,0.4$ and 0.2 . The result of the $a_{\mathrm{Ga}}$ obtained for $x_{\mathrm{Ga}}=0.6$ by Bergman et al. ${ }^{[26]}$ is slightly more positive. Calculated activity of gallium is in good agreement with the experimental results at 1273 and $1400 \mathrm{~K}$.

The comparison of the enthalpies of mixing of the liquid Au-Ga alloys between calculated results and experimental values, which were obtained in the temperature range from 774 to $1660 \mathrm{~K}$, are shown in Fig. 7. All experimental results obtained from the calorimetric method show negative values of the enthalpy of mixing in the liquid phase. The experimental data obtained by Gather and Blachnik, ${ }^{[25]}$ Bergman et al., ${ }^{[26]}$ Hayer et al. ${ }^{[27]}$ and Beja ${ }^{[28]}$ and Jendrzejczyk-Handzlik ${ }^{[29]}$ are compatible with one another. Experimental values reported by Itagaki and Yazawa ${ }^{[23]}$ and Predel and Stein ${ }^{[24]}$ are less negative than the values reported in Ref 25-29. In the literarure Ref 21, 22 there are two different interpretations of this enthalpy temperature dependence. Liu et al. ${ }^{[21]}$ assumed temperature independent heat of mixing in this system. They used all available 
Fig. 8 Calculated enthalpies of formation at $298 \mathrm{~K}$ in the $\mathrm{Au}-\mathrm{Ga}$ system and comparison with the experimental data. standard state for the elements are fcc for $\mathrm{Au}$ and orthorhombic for $\mathrm{Ga}$ experimental data

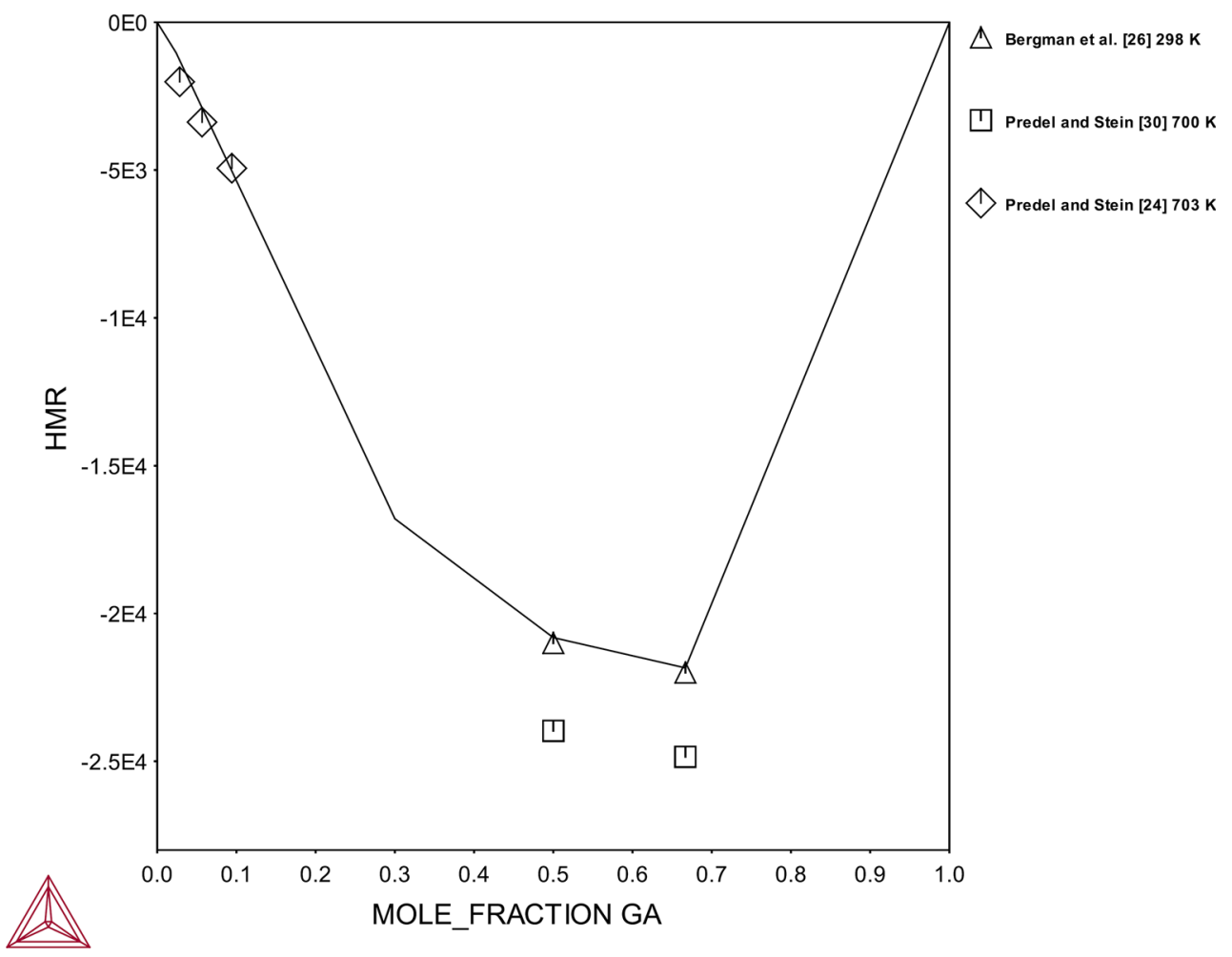

experimental results in Ref 23-28 of the enthalpy of mixing in their optimization, and they reported reasonable agreement between the calculated results and the experimental data. In turn, Wang et al. ${ }^{[22]}$ suggested a temperature dependence of the enthalpy of mixing in the liquid Au-Ga system. However, in their optimization, the experimental values reported by Itagaki and Yazawa ${ }^{[23]}$ and Predel and Stein $^{[24]}$ were not taken into account. The calculated enthalpies of mixing of the liquid Au-Ga alloys are in good agreement with the experimental data Ref 25-28. In both papers Liu et al. ${ }^{[21]}$ and Wang et al. ${ }^{[22]}$ the substitutional solution model was used to describe liquid phase in this binary alloy. In the present work, the experimental values reported by Itagaki and Yazawa ${ }^{[23]}$ and Predel and Stein ${ }^{[24]}$ were not taken into account in optimization of the liquid phase in Au-Ga system. It was assumed that in the examined temperature range (from 774 to $1660 \mathrm{~K}$ ), the enthalpy of mixing in this binary system does not exhibit temperature dependence. It is shown that under this assumption satisfactory agreement is obtained between the calculated values and the experimental data Ref 25-29.

The heat of formation calculated at $298 \mathrm{~K}$ for the solid alloys and intermetallic compounds $\mathrm{AuGa}$ and $\mathrm{AuGa}_{2}$ is shown in Fig. 8. The calculated enthalpies of formation of solid alloys and intermetallic compounds are in good agreement with the experimental data Ref Predel and Stein $^{[24]}$ for fcc( $\left.\mathrm{Au}\right)$ phase and Predel and Schaller ${ }^{[30]}$ and Bergman et al. ${ }^{[26]}$ for $\mathrm{AuGa}$ and $\mathrm{AuGa}_{2}$ phases.
This result is similar to that obtained by Liu et al. ${ }^{[21]}$ However, further experimental investigations to measure the standard enthalpy of formation should be done.

Summarizing, a new set of thermodynamic parameters was proposed for thermodynamic description of the binary gold-gallium system. Calculations done be using this set of thermodynamic parameters reproduced experimental data well, thus the thermodynamic database can be used not only for the description of the binary system but also as part of the description of higher-ordered systems.

Acknowledgments This work realized at AGH University of Science and Technology, Faculty of Non-Ferrous Metals under Grant Number IP2011020471 was supported by the Ministry of Science and Education.

Open Access This article is distributed under the terms of the Creative Commons Attribution 4.0 International License (http://creative commons.org/licenses/by/4.0/), which permits unrestricted use, distribution, and reproduction in any medium, provided you give appropriate credit to the original author(s) and the source, provide a link to the Creative Commons license, and indicate if changes were made.

\section{References}

1. C. Cretu and E. van der Lingen, Coloured Gold Alloy, Gold Bull., 1999, 32, p 115-126

2. C.W. Corti, Blue, Black and Purple. The Special Colours of Gold, The Santa Fe Symposium, E. Bell, Ed., Met-Chem Research, Albuquerque, 2004, p 121-133 
3. V.K. Bhatia, F.C. Levey, C.S. Kealley, A. Down, and M.B. Cortie, The Aluminium-Copper-Gold Ternary System, Gold Bull., 2009, 42, p 201-208

4. EP 0284699 S. Steinemann, Intermetallische Verbindung und ihre Verwendung, 1987

5. EP 1175515 (A1) L.P. Chuma, Jewellery Alloy Compositions, 2002

6. U.E. Klotz, Metallurgy and Processing of Coloured Gold Intermetallics: Part I: Properties and Surface Processing, Gold Bull., 2010, 43, p 4-10

7. K. Wongpreedee, T. Tansakul, H.J. Schustere, and K. Chookruvong, Purple Gold: Past, Present, and Future to Ductile Intermetallics, Gold 2006, New Industrial Applications for Gold, Limerick, Ireland (World Gold Council), 2006

8. J. Fischer-Bühner, A. Basso, and M. Poliero, New Opportunities for Blue and Purple Gold in Jewellery Casting, The Santa Fe Symposium, E. Bell, Ed., Met-Chem Research, Albuquerque, NM, 2009, p 151-166

9. V.M. Andronov, I.P. Grebennik, and S.V. Dukarov, Features of Gallium Spreading Over Surfaces of Ag-Au-Ga Thin Films, Funct. Mater., 1997, 4, p 387-391

10. H. Du, C.H. Champness, I. Shih, and T. Cheung, Growth of Bridgman ingots of CuGaxIn1 - xSe2 for Solar Cells, Thin Solid Films, 2005, 480, p 42-45

11. Y. Zhang, J.B. Li, J.K. Liang, Q. Zhang, B.J. Sun, Y.G. Xiao, and G.H. Rao, Subsolidus Phase Relations of the Cu-Ga-N System, $J$. Alloys Compd., 2007, 438, p 158-164

12. G.M. Kuznetsov and Y.I. Shmelev, Alloys of the Systems Au-Ga and Si-Au-Ga, Inorg. Mater. USSR, 1974, 10, p 1078-1082

13. L. Gomidzelovic, D. Zivkovic, L. Balanovic, and D. Minasijevic, Ternary Au-Ga-Sb System: Calculation of Thermodynamic Properties Using General Solution Model, Rare Met., 2016, 35, p 262-268

14. D. Manasijevic, D. Zivkovic, D. Talijan, N. Cosovic, V. Gomidzelovic, L. Todorovic, and R. Minic, Thermal Analysis and Thermodynamic Prediction of the Phase Equilibria in the Ternary Au-Ga-Sb System, J. Phys. Chem. Solids, 2013, 74, p 280-285

15. T.C. Thomas and R.S. Williams, Solid Phase Equilibria in the $\mathrm{Au}-\mathrm{Ga}-\mathrm{As}$, Au-Ga-Sb, Au-In-As and Au-In-Sb Ternaries, J. Mater. Res., 1986, 1, p 352-360

16. M. Ghasemi, B. Sundman, S.G. Fries, and J. Johansson, The thermodynamic Assessment of the Au-In-Ga System, J. Alloys Compd., 2014, 600, p 178-185

17. D. Mouani, G. Morgant, and B. Legendre, Study of the Phase Equilibria in the Ternary Gold-Gallium-Tellurium System, $J$. Alloys Compd., 1995, 226, p 222-231

18. M. Matsushita, Y. Sasaki, and Y. Ikuta, Investigation of a New Sn-Cu-Ga Alloy Solder, Defect Diffus. Forum, 2011, 518, p 312-315

19. W. Gierlotka and D. Jendrzejczyk-Handzlik, Thermodynamic Description of the Binary Ag-Ga System, J. Alloys Compd., 2011, 509, p 38-42

20. D. Jendrzejczyk-Handzlik, K. Fiztner, and W. Gierlotka, On the $\mathrm{Cu}-\mathrm{Ga}$ system: Electromotive Force Measurement and Thermodynamic Reoptimization, J. Alloys Compd., 2015, 621, p 287-294

21. J. Liu, C. Guo, C. Li, and Z. Du, Thermodynamic Assessment of the Au-Ga system, J. Alloys Compd., 2011, 508, p 62-70

22. J. Wang, Y.J. Liu, L.B. Liu, H.Y. Zhou, and Z.P. Jin, Thermodynamic Assessment of the Au-Ga Binary System, Calphad, 2011, 35, p 242-248

23. K. Itagaki and A. Yazawa, Heats of Mixing in Liquid Copper or Gold Binary Alloys, Trans. JIM, 1975, 16, p 679-686

24. B. Predel and D.W. Stein, A Thermodynamic Investigation of the Binary Systems of Gallium with Copper, Silver, and Gold, Acta Metall., 1972, 20, p 515-522
25. B. Gather and R. Blachnik, A Simple Heat-Flow Calorimeter and the Excess Enthalpies of (Gold + Gallium) and (Gold + Indium), J. Chem. Thermodyn., 1984, 16, p 487-495

26. C. Bergman, J.P. Bros, M. Carbonel, M. Gambino, and M. Laffitte, Propriétés Thermodynamiques des Alliages Binaires OrGallium, Rev. Int. Hautes Temp. Refract., 1971, 8, p 205-210

27. E. Hayer, K.L. Komarek, M. Gaune-Escard, and J.P. Bros, A Thermodynamic Investigation of the Gold-Gallium System, $Z$. Metallkde., 1990, 81, p 233-238

28. R. Beja, Sci. Phys. Ph.D. Thesis, No AO 3656, Université AixMarseille, 1969

29. D. Jendrzejczyk-Handzlik, Enthalpies of mixing of liquid Ag-Ga, Au-Ga and Ag-Au-Ga alloys, J. Chem. Thermodyn., 2017 (accepted to publish)

30. B. Predel and D.W. Stein, Bildungsenthalpien Binärer Verbindungen des Galliums mit Kupfer, Silber und Gold Sowie Analyse der Thermodynamischen Eigenschaften von 3/2-Elektronen-Verbindungen (Enthalpies of Formation of Binary Compounds of Gallium with Copper, Silver and Gold and the Analysis of Thermodynamic Properties of 3/2-Electron-Compounds), Acta Metall., 1972, 20, p 681-692

31. R.C. Wallbrecht, R. Blachnik, and K.C. Mills, The Heat Capacity and Enthalpy of Some Phases Formed by Copper, Silver and Gold. Part III. $\mathrm{Cu}+\mathrm{Ga}, \mathrm{Ag}+\mathrm{Ga}, \mathrm{Au}+\mathrm{Ga}, \mathrm{Cu}+\mathrm{In}, \mathrm{Ag}+\mathrm{In}$ and $\mathrm{Au}+$ In Systems, Thermochim. Acta, 1981, 48, p 69-82

32. K. Kameda and T. Azakami, Activities of Gallium and Bismuth in Liquid Gold Base Binary Alloy System, J. Jpn. Inst. Met., 1976, 40, p 1087-1092

33. B. Predel and U. Schallner, Undersuchung der Thermodynamischen Eigenschaften Flussinger Binärer Legierungen des Silbers und Goldes mit Gallium, Indium und Germanium (Investigation of the Thermodynamic Properties of Binary Liquid Alloys of Silver and Gold with Gallium, Indium and Germanium), $Z$. Metallkd., 1972, 63, p 341-347

34. F. Weibke and E. Hesse, Über die Legierungen des Galliums mit Gold, Z. Anorg. Chem., 1939, 240, p 289-299

35. E.A. Owen and E.A.O. Roberts, The Solubility of Certain Metals in Gold, J Inst. Met., 1945, 71, p 213-254

36. C.J. Cooke and W. Hume-Rothery, The Equilibrium Diagram of the System Gold-Gallium, J. Less Common Met., 1966, 10, p 42-51

37. D. Zivkovic, L. Gomidzelovic, D. Minasijevic, N. Talijan, and V. Cosovic, Calorimetric Study and Phase Diagram Investigation of the Au-Ga System, Int. J. Mater. Res., 2013, 104, p 554-560

38. C.J. Cooke and W. Hume-Rothery, On the Structures of Copper, Silver and Gold Alloys, J. Less Common Met., 1966, 10, p 52-56

39. K. Frank, Kristallstruktur von $\mathrm{Au}_{7} \mathrm{Ga}_{2}$ (h) (The Crystal Structure of $\left.\mathrm{Au}_{7} \mathrm{Ga}_{2}(\mathrm{~h})\right)$, J. Less Common Met., 1971, 23, p 83-87

40. W. Wallace and W.J. Kitchingman, On the $\beta$ Phase of the GoldGallium System, J. Less Common Met., 1969, 17, p 263-270

41. M. Puselj and K. Schubert, Kristallstruktur von $\mathrm{Au}_{2} \mathrm{Ga}$ (The Crystal Structure of $\mathrm{Au}_{2} \mathrm{Ga}$ ), J. Less Common Met., 1974, 38, p 83-90

42. R.P. Elliot and F.A. Shumnk, The Au-Ga (Gold-Gallium) System, Bull. Alloys Phase Equilib., 1981, 2, p 356-358

43. W.G. Moffatt, Handbook of Binary Phase Diagrams, General Electric Co., Schenectady, 1977

44. T. Masalski and H. Okamoto, Au-Ga (Gold-Gallium), Binary Alloy Phase Diagrams, American Society for Metals International, Russell Township, 1974

45. A.T. Dinsdale, SGTE Pure Elements (Unary) Database, Version 4.5, 2006

46. I. Ansara, Thermodynamic Modelling of Solution Phases and Phase Diagram Calculations, Pure Appl. Chem., 1990, 62, p 71-78

47. O. Redlich and A.T. Kister, Algebraic Representation of Thermodynamic Properties and the Classification of Solutions, Ind. Eng. Chem., 1948, 40, p 345-348 
48. H.S. Liu, Y. Cui, K. Ishida, and Z.P. Jin, Thermodynamic Reassessment of the Au-In Binary System, Calphad, 2003, 27, p 27-37

49. H.S. Liu, C.L. Liu, K. Ishida, and Z.P. Jin, Thermodynamic Modeling of the Au-In-Sn System, J. Electron. Mater., 2003, 32, p 1290-1296

50. H. Pfisterer and K. Schubert, New Phases of MnP(B31) Type, Z. Metallkd., 1950, 41, p 358-367

51. ThermoCalc v., Foundation Computational Thermodynamic, Stockholm, Sweden, 2015, p 2014

52. R. Schmid-Fetzer, D. Andersson, P.Y. Chevalier, L. Eleno, O. Fabrichnaya, U.R. Kattner, B. Sundman, C. Wang, A. Watson, L.
Zabdyr, and M. Zinkevich, Assessment Techniques, Database Design and Software Facilities for Thermodynamics and Diffusion, Calphad, 2007, 2007(31), p 38-52

53. W. Gierlotka, J. Łapsa, and D. Jendrzejczyk-Handzlik, Thermodynamic Description of the $\mathrm{Pb}$-Te System Using Ionic Liquid Model, J. Alloys Compd., 2009, 479, p 152-156

54. W. Gierlotka, D. Jendrzejczyk-Handzlik, P. Handzlik, and K. Fitzner, On the Ternary Ag-Cu-Ga System: Electromotive Force Measurement and Thermodynamic Modeling, J. Alloys Compd., 2015, 646, p 1023-1031 